\title{
Synovial Membrane
}

National Cancer Institute

\section{Source}

National Cancer Institute. Synovial Membrane. NCI Thesaurus. Code C12473.

The inner layer of the connective tissue that seals the joint. 